\title{
Giant basal cell carcinoma
}

Carcinoma basocelular gigante

\author{
Nilton Nasser ${ }^{1}$ \\ Bruno Trauczynski Neto ${ }^{3}$
}

\author{
Nilton Nasser Filho ${ }^{2}$ \\ Lissandra Melati da Silva ${ }^{4}$
}

\begin{abstract}
The basal cell carcinoma is the most common skin cancer but the giant vegetating basal cell carcinoma reaches less than $0.5 \%$ of all basal cell carcinoma types. The Giant BCC, defined as a lesion with more than $5 \mathrm{~cm}$ at its largest diameter, is a rare form of BCC and commonly occurs on the trunk. This patient, male, 42 years old presents a Giant Basal Cell Carcinoma which reaches $180 \mathrm{~cm} 2$ on the right shoulder and was negligent in looking for treatment. Surgical treatment was performed and no signs of dissemination or local recurrence have been detected after follow up of five years.

Keywords: Carcinoma, basal cell; Neoplasms, basal cell; Skin abnormalities; Skin neoplasms

Resumo: O carcinoma basocelular é o tipo mais comum de câncer de pele, mas o carcinoma basocelular gigante vegetante não atinge $0,5 \%$ de todos os tipos de carcinomas basocelulares. $\mathrm{O}$ Carcinoma Basocelular Gigante, definido como lesão maior que $5 \mathrm{~cm}$ no maior diâmetro, é uma forma rara de carcinoma basocelular e comumente ocorre no tronco. Este paciente apresenta um Carcinoma Basocelular Gigante com $180 \mathrm{~cm}^{2}$ no ombro direito e foi negligente em procurar tratamento. Foi realizado tratamento cirúrgico e nenhum sinal de disseminação ou recorrência local foi detectada após 5 anos.

Palavras-chave: Anormalidades da pele; Carcinoma basocelular; Neoplasia de células basais; Neoplasias cutâneas
\end{abstract}

\section{INTRODUCTION}

The basal cell carcinoma is the most common skin cancer but a giant vegetating basal cell carcinoma reaches less than $0.5 \%$ of the all basal cell carcinoma (BCC) types. ${ }^{1-4}$ The Giant BCC (GBCC), defined as a lesion with more than $5 \mathrm{~cm}$ at its largest diameter, is a rare form of BCC and commonly occurs on the trunk.

The GBCC can be an aggressive tumor with local invasion and metastatic in $50 \%$ of the cases. ${ }^{3}$ In this case the patient is an engineer and because of his negligence the tumor reaches more than $150 \mathrm{~cm}^{2}{ }^{2}$

\section{CASE REPORT}

The patient is male, 52 years old, engineer, married, living in an industrial area in the south of Brazil. He reported that it had begun as a small tumor on the right shoulder seven years ago, growing quickly in the last two years and that he was afraid to look for a dermatologist.

Dermatological examination: The patient had a vegetating and exophytic tumor measuring $15 \mathrm{~cm}$ in length $\times 12 \mathrm{~cm}$ in width and $5 \mathrm{~cm}$ in height $\left(180 \mathrm{~cm}^{2}\right)$,

\footnotetext{
Received on 29.05.2011.

Approved by the Advisory Board and accepted for publication on 30.06.2011.

* Study carried out in a private clinic and at the Course of Medicine, Regional University of Blumenau Foundation (Fundação Universidade Regional de Blumenau - FURB) - Blumenau (SC), Brazil.

Conflict of interest: None

Financial funding: None

PhD in Dermatology - Full Professor at Regional University of Blumenau Foundation (Fundação Universidade Regional de Blumenau - FURB) - Blumenau (SC), Brazil.

Physician, Resident in Dermatology at the General Polyclinic of Rio de Janeiro (Policlínica Geral do Rio de Janeiro - PGRJ) - Rio de Janeiro (RJ), Brazil.

Thoracic Surgeon - Member of Santa Isabel Hospital (Hospital Santa Isabel - Blumenau (SC), Brazil.

Doctor. Private clinic - Blumenau (SC), Brazil.

(C)2012 by Anais Brasileiros de Dermatologia
} 
elevated and irregular borders, with necrosis and ulcerated in the center in a non-sun-exposed skin area of the right shoulder. There was granulation tissue on all surfaces, release of fluid with pustules and hemorrhagic points (Figures 1 and 2).

The characteristics of this tumor define it as a Giant exophytic basal cell carcinoma. The patient was subjected to total surgical removal of the tumor. The histological examination showed changes in the overlying epidermis, with ulcerated areas, islands of basaloid cells with pleomorphic and hyperchromatic nuclei, and scant poorly demarcated cytoplasm; mitotic figures; apoptotic cells. Rounded islands of cells with peripheral palisading infiltrated the adjacent fibrous stroma. The histopathology confirmed a basal cell carcinoma (Figure 3).

The patient had an excellent evolution and a follow up of five years showed a scar without dissemination or recurrence and total cure of the tumor (Figure 4).

\section{DISCUSSION}

The Giant BCC is normally defined as a BCC with more than $5 \mathrm{~cm}$ at its largest diameter (American Joint Committee on Cancer) ${ }^{1-4}$

The Giant BCC is a rare form of BCC and commonly occurs on the trunk, and displays a more aggressive behavior, resulting in local invasion and metastasis in $50 \%$ of the cases. ${ }^{1.5}$

The reported incidence of metastatic BCC ranges from $0.03 \%$ to 0.55 .

There is no report about metastasis lesions in this case.

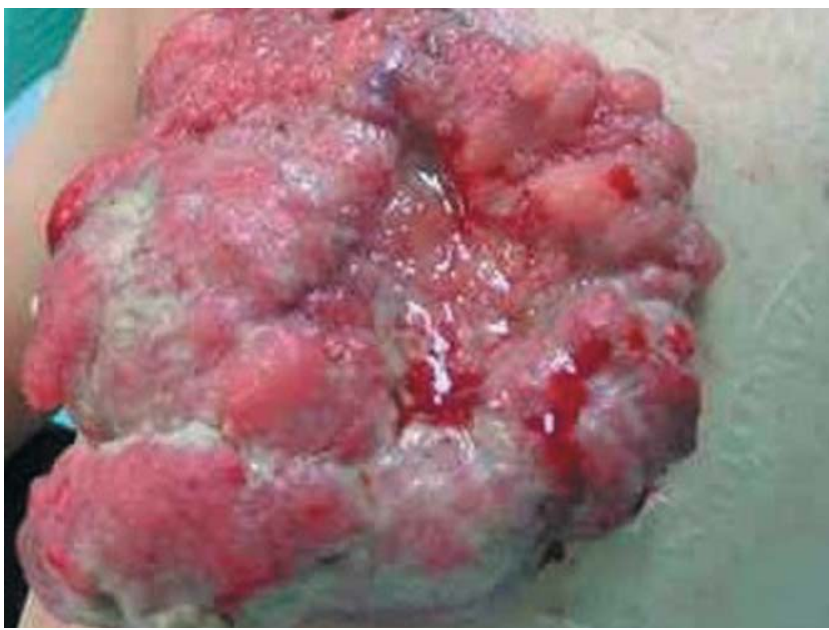

Figure 1: Giant basal cell carcinoma - Tumor on the right shoulder, on unexposed skin area, $15 \mathrm{~cm}$ long $x 12 \mathrm{~cm}$ wide and $5 \mathrm{~cm}$ high $\left(180 \mathrm{~cm}^{2}\right)$

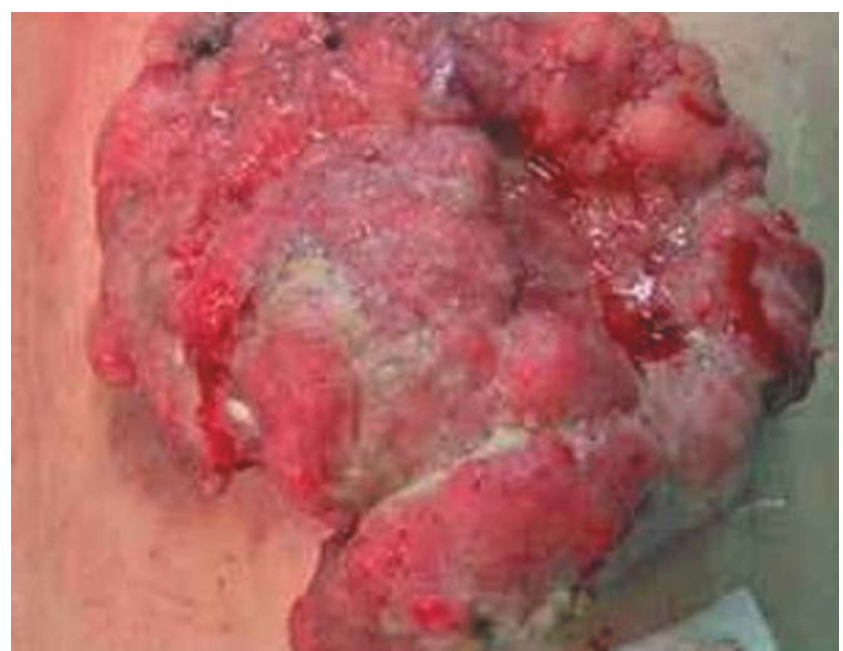

FigURE 2: Giant basal cell carcinoma - Close-up picture of the lesion

The majority of the patients do not presents common risk factor like chronic sun exposure, arsenic exposure, alcoholism, scars, etc. ${ }^{1}$

Cigarette smoking is associated with an increased prevalence of basal cell carcinomas larger than $1.0 \mathrm{~cm}$ in diameter. Among patients with tumors greater than or equal to $5.0 \mathrm{~cm}, 50 \%$ were smokers. ${ }^{6}$

In this case, the patient was a nonsmoker, did not customarily drink alcoholic beverages, had a sound mind, and the tumor was situated in an unexposed area.

There is a relation between negligence and tumor growth in $30 \%$ of the cases. ${ }^{5-8}$ Reclusive patients or patients who neglect the lesions for long

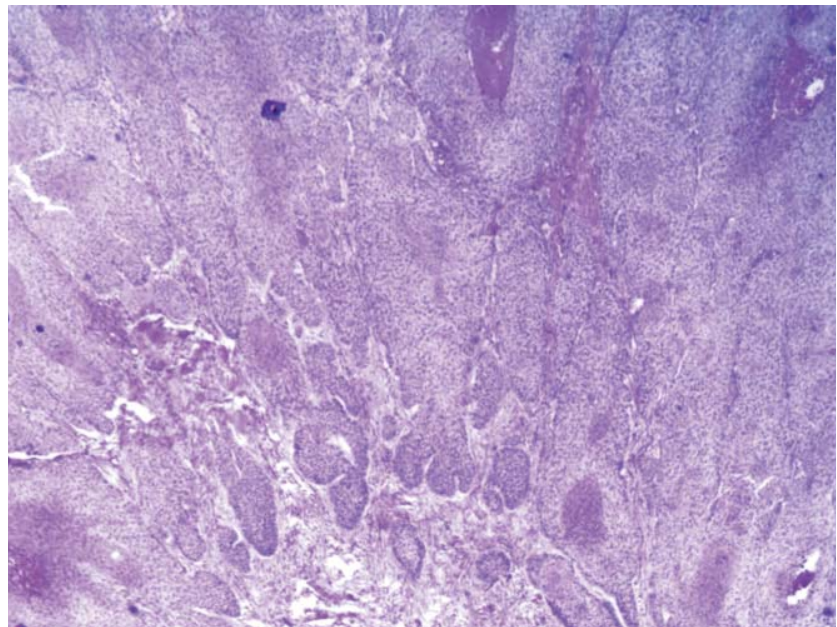

FIGURE 3: Giant basal cell carcinoma - Histopathology - The histological examination revealed changes in the overlying epidermis, with ulcerated areas, islands of basaloid hyperchromatic nuclei, scant poorly demarcated cytoplasm, mitotic figures and apoptotic cells. Rounded islands of cells with peripheral palisading infiltrated the adjacent fibrous stroma 


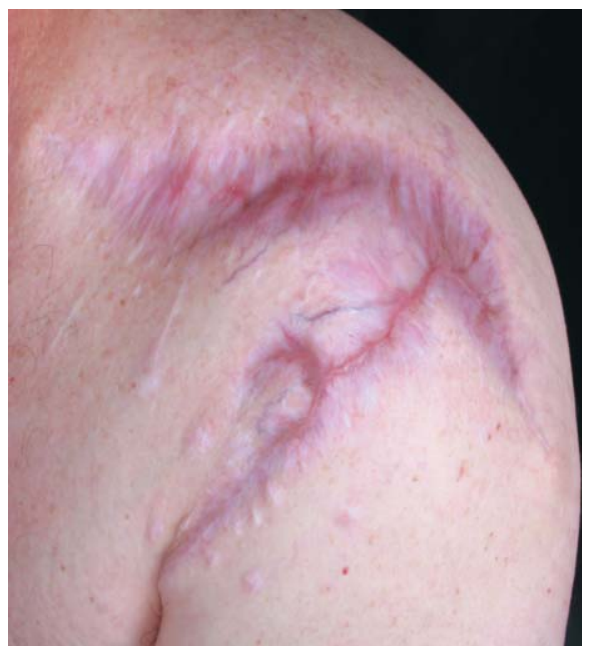

FigURE 4: Giant basal cell carcinoma - Surgical scar after 5 months

\section{REFERENCES}

1. Northington M, Tamburin L, Hamza S, Diwan H, Skelton H, Smith K. Giant basal cell carcinoma associated with human papillomaviruses infection. J Cutan Pathol. 2004;31:174-8

2. Takemoto S, Fukamizu H, Yamanaka K, Nakayama T, Kora Y, Mineta H. Giant basal cell carcinoma: improvement in the quality of life after extensive resection. Scand J Plast Reconstr Surg Hand Surg. 2003;37:181-5.

3. Scanlon EF, Volkmer DD, Oviedo MA, Khandekar JD, Victor TA. Metastatic basal cell carcinoma. J Surg Oncol. 1980;15:171-80.

4. Sahl WJ Jr, Snow SN, Levine NS. Giant basal cell carcinoma. Report of two cases and review of the literature. J Am Acad Dermatol. 1994;30(5 Pt 2):856-9.

5. Lorenzini M, Gatti S, Giannitrapani A. Giant basal cell carcinoma of the thoracic wall: a case report and review of the literature. Br J Plast Surg. 2005,58:1007-10.

6. Smith J, Randle HW. Giant basal cell carcinoma and cigarette smoking. Cutis. 2001;67:73-6.

7. Rossi R, Campolmi P, Giomi B, Massi D, Cappugi P. Giant exophytic basal cell carcinoma treated with radiotherapy. J Eur Acad Dermatol Venereol. 2002;16:374-6.

8. Manstein $\mathrm{CH}$, Gottlieb N, Manstein ME, Manstein G. Giant basal cell carcinoma: a series of seven T3 tumors without metastasis. Plast Reconstr Surg. 2000;106:653-6. periods of time are more likely to have giant invasive tumors. 2,5

The GBCC found had a 7-year progression and the patient did not look for medical care because he was afraid of the disease (negligence).

The clinical form of this GBCC is exophytic and vegetating; differential diagnosis compares it with Squamous Cell Carcinoma. ${ }^{2,4,7,9,10}$
9. Lackey PL, Sargent LA, Wong L, Brzezienski M, Kennedy JW. Giant basal cell carcinoma surgical management and reconstructive challenges. Ann Plast Surg. 2007;58:250-4.

10. Unlü RE, Orbay H, Uysal AC, Alagöz MS, Kilinc H, Sensöz O, et al. Unusual and giant tumors of head and neck region. J Craniofac Surg. 2006;17:1219-29.

\author{
MAILING ADDRESS: \\ Nilton Nasser \\ Rua Curt Hering, 20 - $3^{\circ}$ andar - Centro \\ 89010-030 Blumenau - Santa Catarina, SC \\ E-mail:ninasser.bnu@terra.com.br
}

How to cite this article: Nasser N, Nasser Filho N, Trauczynski Neto B, Silva LM. Giant basal cell carcinoma. An Bras Dermatol. 2012;87(3):469-71. 